\title{
Closing the Gender Gap in Education: Does it Foretell the Closing of the Employment, Marriage, and Motherhood Gaps?
}

\section{Citation}

Ganguli, Ina, Ricardo Hausmann, and Martina Viarengo. 2011. Closing the Gender Gap in Education: Does it Foretell the Closing of the Employment, Marriage, and Motherhood Gaps? HKS Faculty Research Working Paper Series and Center for International Development Working Papers (RWP11-021 and 220), John F. Kennedy School of Government, Harvard University

\section{Published Version}

http://web.hks.harvard.edu/publications/workingpapers/citation.aspx?Publd=7836

\section{Permanent link}

http://nrs.harvard.edu/urn-3:HUL.InstRepos:5027209

\section{Terms of Use}

This article was downloaded from Harvard University's DASH repository, and is made available under the terms and conditions applicable to Other Posted Material, as set forth at http:// nrs.harvard.edu/urn-3:HUL.InstRepos:dash.current.terms-of-use\#LAA

\section{Share Your Story}

The Harvard community has made this article openly available.

Please share how this access benefits you. Submit a story.

Accessibility 


\section{Closing the Gender Gap in Education: Does it Foretell the Closing of the Employment, Marriage, and Motherhood Gaps?}

\section{Faculty Research Working Paper Series}

\section{Ina Ganguli}

Harvard Kennedy School

Ricardo Hausmann

Harvard Kennedy School

\section{Martina Viarengo}

Harvard Kennedy School

\section{May 2011 RWP11-021}

The views expressed in the HKS Faculty Research Working Paper Series are those of the author(s) and do not necessarily reflect those of the John F. Kennedy School of Government or of Harvard University. Faculty Research Working Papers have not undergone formal review and approval. Such papers are included in this series to elicit feedback and to encourage debate on important public policy challenges. Copyright belongs to the author(s). Papers may be downloaded for personal use only. 


\section{Closing the Gender Gap in Education: Does it Foretell the Closing of the Employment, Marriage, and Motherhood Gaps?}

Ina Ganguli, Ricardo Hausmann, and Martina Viarengo CID Working Paper No. 220

April 2011

(c) Copyright 2011, Ina Ganguli, Ricardo Hausmann, and Martina Viarengo and the President and Fellows of Harvard College

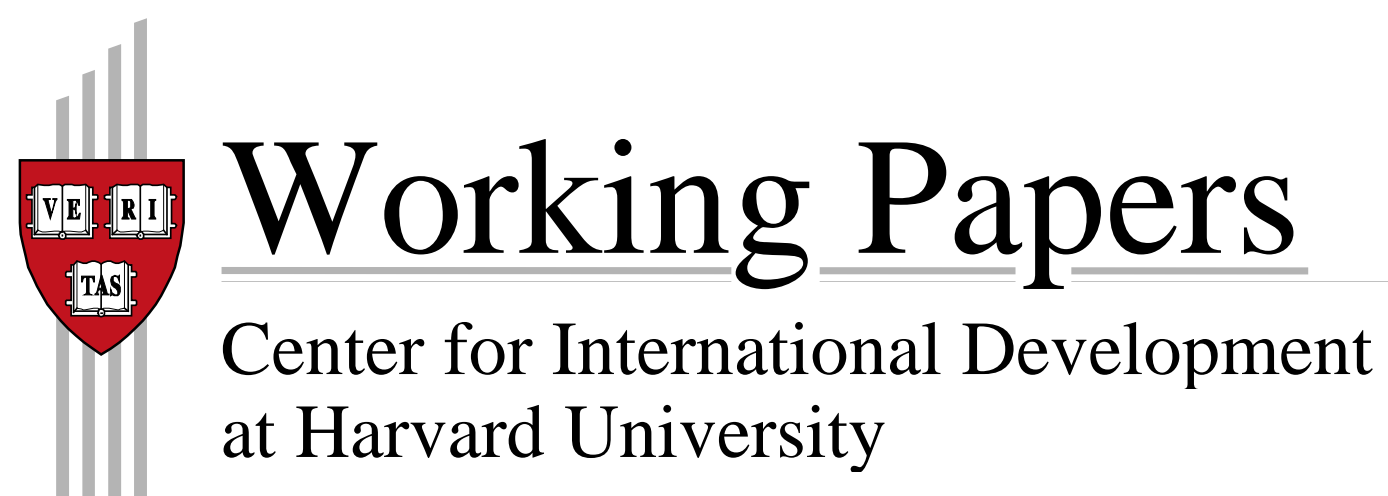




\title{
Closing the Gender Gap in Education: Does it Foretell the Closing of the Employment, Marriage, and Motherhood Gaps? ${ }^{1}$
}

\author{
Ina Ganguli, Ricardo Hausmann and Martina Viarengo \\ Harvard University, John F. Kennedy School of Government
}

April 28, 2011

\begin{abstract}
In this paper we examine several dimensions of gender disparity for a sample of 40 countries using micro-level data. We start by documenting the reversal of the gender education gap and ranking countries by the year in which it reversed. Then we turn to an analysis of the state of other gaps facing women: we compare men and women's labor force participation (the labor force participation gap), married and single women's labor force participation (the marriage gap), and mothers' and non-mother's labor force participation (the motherhood gap). We show that gaps still exist in these spheres in many countries, though there is significant heterogeneity among countries in terms of the size of and the speed at which these gaps are changing. We also show the relationship between the gaps and ask how much the participation gap would be reduced if the gaps in other spheres were eliminated. In general, we show that while there seems to be a relationship between the decline of the education gap and the reduction of the other gaps, the link is rather weak and highly heterogeneous across countries.
\end{abstract}

Keywords: development, gender gap, education

JEL subject codes: O12, J16, I2

\footnotetext{
${ }^{1}$ We gratefully acknowledge support received from the Women and Public Policy Program, the Women's Leadership Board at Harvard Kennedy School, and the Center for International Development at Harvard University. We would like to thank Iris Bohnet, Marcela Escobari, and Lant Pritchett for helpful discussions. The usual caveats apply.
} 


\section{$\underline{\text { I. Introduction }}$}

Eliminating differences in education between men and women has been a priority of development organizations and the international community for many years. The Millennium Development Goal (MDG) to "eliminate gender disparity in primary and secondary education, preferably by 2005, and in all levels of education no later than 2015” is pursued by institutions like the United Nations and the World Bank. According to the World Bank, "there is no investment more effective for achieving development goals than educating girls.” Equality of educational opportunities between men and women was also been acknowledged in the Universal Declaration of Human rights of $1948 .{ }^{1}$ It has been suggested [in the literature] that educating girls and achieving the MDG goal on gender equity will lead to a range of improved outcomes for developing countries (see e.g. Schultz, 2002), including higher economic growth (e.g. Abu-Ghaida and Klasen, 2004). In many countries, the differences in education between men and women has disappeared, or even reversed. This reversal of the gender education gap has occurred in almost all developed countries and many developing countries as well, even among cohorts born over 60 years ago in several countries.

After reversing the gender education gap, have these countries also made progress in closing other gender gaps? What have we observed regarding gender equality and women's empowerment in terms of participation - married women versus single women and mothers and non-mothers' participation? How have developed countries fared relative to developing countries?

In this article, we use International Integrated Public Use Microdata Series (IPUMSInternational) Census data from 40 countries to document the reversal of the gap and to rank countries by the year in which the gender education gap reversed. We then turn to an analysis of 
the state of other gaps facing women comparing the participation gap, the marriage gap, and the motherhood gap. We show that gaps still exist in these spheres in many countries, although there is significant heterogeneity in terms of the size of the gaps and the speed at which they are changing. Finally, we investigate the relationship between the gaps.

\section{$\underline{\text { II. Motivation }}$}

Evidence has shown that educating women can lead to improved economic and social outcomes. Specifically, recent empirical work, which has primarily focused on developing countries, shows that there are both positive economic consequences and social externalities arising from improving women's education. For example, increases in women's education have been associated with reductions in fertility (e.g. Osili and Long, 2008), decreases in infant mortality and increases in life expectancy (see Dancer et al., 2008; Behrman and Deolalikar, 1988). Overall, it appears that educating women has beneficial effects on children's health (see Glewwe, 2000), schooling, and adult productivity (Lam and Duryea, 1999; Strauss and Thomas 1995). It holds a larger beneficial effect than the same level of father's education (see Schultz 2002). In addition, studies have shown that the benefits from expanding female education are far greater than the benefits from other public interventions, such as improving family planning service provision or increasing the number of physicians in the population (Kingdon, 2002). Empirical evidence also shows that a low investment in women's education leads to slower economic growth and reduced income levels (Dollar and Gatti, 1999; Klasen 1999).

Why would we expect changes in other measures of gender disparity as a result of increases in women's education? We next discuss the theoretical reasoning behind the potential 
effect of narrowing the education gap on women's participation by married and unmarried women and by those with and without children.

\section{a. Labor Force Participation and Earnings}

The theory of human capital investment relates differences in earnings to differences in schooling, training, and other assets (Mincer, 1974; Becker, 1991). Specifically, it relates expected lifetime labor force participation to one’s incentive to acquire education and training. According to this theory, education increases the productivity, and thus, the earnings of individuals. Existing studies have established a strong, causal relationship between education and income at the individual level. ${ }^{2}$

As Becker (1992) suggests, human capital theory explains why women have traditionally had fewer incentives to invest in education and training given their shorter expected labor force participation. Many factors have been put forward to explain why this has changed over time and why the gender gap in education has closed and even reversed in many countries. In the case of the United States., the technological change that led to the use of mechanical rather than human energy (Galor and Weil 2000), the rapid expansion of the service sector (Becker, 1992); as well as changes in household work through the use of piped water, electricity, and appliances (Killingsworth and Heckman, 1986; Greenwood et al., 2005; Goldin 2006); greater ability to control pregnancies through access to birth-control technology, and lower effort costs of college preparation and attendance for girls than for boys, (Goldin and Katz, 2006). Also, the increase in divorce rates and decline in family size, have been suggested as correlates and possible determinants of the reversal of the gender gap in education. 
The increases in education have allowed women to increase their expected lifetime laborforce participation, shifting their time horizon. Consequently, their expected benefits from an increased investment in education, leading them to plan "careers" instead of having "jobs" and being the "secondary worker" within the household (Goldin 2006). In this regard, research shows that returns on women's education in many countries are either equal or higher than those for men. Consequently, the opportunity cost of staying home increases as women's level of education increases.

\section{b. Marriage and Labor Force Participation}

Married women's labor force participation has been the subject of much debate in the literature. Mincer's (1962) model was the first that tried to explain the apparent puzzle of the increase in married women's labor force participation in spite of steady increases in men's real earnings in the United States. He found the positive substitution effect of general wage increases on women's employment to be greater than the negative income effect through the husband's wage, with the difference being large enough for increases in women's wages to explain much of the increase in married women's labor force participation.

Goldin (1990) shows how changes in income and wage elasticities can affect the evolution of women's labor force participation, while Blau and Kahn (2007) examine trends in married women's own- and cross-wage elasticities. They find that in the United States from 1980-2000, married women's own-wage elasticity fell by about one-half and their responsiveness to husbands' wages declined by about 40 percent. Heim (2007) also examines U.S.' married women's labor supply elasticities over 1979-2002 finding that married women's 
wage and income elasticities for both participation and hours decreased dramatically in absolute value over the period.

Juhn and Murphy (1997) focus on women's employment and earnings and examine it at different points of the husbands' wage distribution from 1959 to 1989 and find an increasingly weaker relationship between women's labor force participation and their husbands' earnings. They also confirm a positive relationship between women's wages and labor force participation, casting doubts on the increase in married women's labor force participation to compensate the low earnings growth of their husbands. In addition to economic factors, Fernandez (2007) shows how changes in culture and social norms as part of a rational intergenerational learning process may have affected the increase in married women's participation in the workforce.

\section{c. Fertility and Labor force Participation}

In the neoclassical model of the family, women tended to specialize in domestic production, including child rearing and traditional household activities whereas men were the primary earners and specialized in formal production through labor market activities (Mincer, 1962; Becker 1991). Moreover, even for women in the labor force, rearing children in the early years was associated with a decrease in working experience and wages. Subsequent models found the neoclassical model to be inadequate in explaining the rise in married women's employment (e.g., Bowen and Finegan, 1969; Smith and Ward, 1985) and focused on other factors to explain the evolution of mothers' labor force participation.

First, the expansion of education appears to be related to a decline in fertility rates (Caldwell, 1980; Galor and Weil, 1996 and 1999) and to a delay in the start of fertility (see Strauss and Thomas (1995) for a review of the existing literature). According to Caldwell 
(1982), education influences fertility by increasing the cost of children and the importance of investing in children's human capital, leading women's optimal fertility choices toward higher quality (Becker and Lewis, 1973; Willis 1973). Becker et al. (1990) show how higher levels of human capital lead to an increase in the returns on human capital, as well as to fewer children. Galor and Weil (1996) relate increases in women's wages to the decline in fertility, which, in their theoretical framework, is a consequence of the increase in the cost of children more than the increase in household income. Several studies in the recent literature have tried to establish a causal relationship between education and fertility in order to address issues of reverse causality and possible omitted variables (e.g. Breierova and Duflo, 2004; McCrary and Royer, 2008; Duflo, Kremer and Dupas, 2010).

Second, advances in household production technology have reduced the time necessary for domestic production. In addition, advances in medical technology have reduced the time associated with childbirth and rearing (Barker and Feiner, 2004), allowing women to return to the labor force faster. Third, the shift of economic activity toward the service sector and the consequent introduction of scheduled part-time employment, which is more "female friendly", as well as the increase in returns to education, has led to an expansion of married women and mothers' labor force participation (Goldin, 2006; Goldin et al., 2006), increasing educated women’s opportunity cost of staying out of the labor force (Attanasio et al., 2009).

Based on this literature, we would expect that an increase in women's levels of education would lead to an increase in women's labor force participation ${ }^{34}$, higher labor force participation among mothers, lower fertility rates and smaller wage gaps. That is, we would expect that empowering women with more education would increase their economic participation and give them a greater access to economic resources, leading to an improvement in many other spheres. 
A large cross-country analysis of the reversal of the gender education gap and the gender gaps in these other areas is lacking. We provide evidence on the dynamics of the gender gaps in these areas in the remainder of the paper. We also relate the state of the gender gaps to policyrelevant factors such as levels of GDP, urbanization, and labor market rigidity.

\section{Data}

Our analysis is based on a country-year-level dataset constructed using micro-level data for each country. The primary source used to construct the dataset is the IPUMS-International (Minnesota Population Center, 2009), which includes the largest publicly available individuallevel census data and consists of decennial records of persons and households. We draw upon data for select countries from Africa, Asia, Europe, and Latin America as available, drawing upon the most recent wave of the Census for each country. In most cases the difference between the two waves of the census is ten years. The focus of our analysis is one cohort of women and men - those individuals aged 35-44. The motivation for including this age group is to include individuals who have finished their studies and have made the bulk of their marriage, fertility and labor market decisions.. Appendix Table A lists the years and countries for the analytical samples based on the Census data.

Using the Census data for each country, we measure several gender gaps. First, we define the "education gap" as the difference in average years of education between men and women. The "labor force participation gap" is the share of men who are in the labor force (employed or unemployed and job-seeking) minus the share of women who are in the labor force ${ }^{5}$. The "marriage gap" is the difference in rates of employment among women who are 
married (or living in cohabitation) and single women. The "motherhood gap" is the difference in rates of employment among women with three or more children and women without children.

We supplement the measures constructed from the IPUMS Census data with country-

level variables from the World Development indicators, including measures of GDP per capita and urbanization rates. We also include measures of labor market rigidity extracted from the World Bank’s Doing Business dataset.

\section{The Education Gap}

First, we document the reversal of the gender education gap. Figure 1a shows the year of birth of the first cohort where the education gap was closed in the most recent available wave of the census. This corresponds to a wave in the early 2000s in most countries. ${ }^{6}$ Among the 40 countries included in our sample, 27 have closed the gap, while in the remaining 13 countries, men still have higher levels of schooling than women on average. The first country where the gap was closed is Belarus, for the cohort born in 1945, the last are South Africa and Romania for the cohort born in 1975. In the United States, the gap was closed for cohorts born in 1956. Interestingly, in 10 developing countries, the gender gap in years of schooling was closed earlier than in the United States. The timing of the closure of the gender gap in education implies that in countries where the gap was closed in the 1950s, two generations already have experienced gender equality in years of schooling, while in the countries where the education gap was closed in the 1970s, only one generation is experiencing this phenomenon.

Except for Austria, countries where the gender gap has not closed are developing countries. On the other hand, we observe that in most developed countries and also in some developing countries, the gap not only has closed but has significantly reversed (Hausmann et 
al., 2009). Table B shows that the gap in years of schooling at age 25 is still very large in Bolivia, Iraq, China, Palestine, Kenya, and Rwanda, with gaps ranging between 1.2 and 0.6 years of schooling; gaps are much smaller in Austria and Mexico, both with 0.1 years. The gap has closed in Vietnam, and it has reversed significantly in Mongolia, Venezuela, Argentina, Brazil, and Greece where 25 year-old women have between 0.8 and 1.2 years of schooling more than men. Among Latin American countries, the gap has closed and reversed in most of them (8 out of 10). Only Mexico and Bolivia exhibit the existence of a gap, still significant in the case of Bolivia.

Figure $1 \mathrm{~b}$ shows women's average level of education and relates this to the current level of the gender gap. We observe that in most developed countries, the gap is either equal to zero (gender equality) or has reversed. Interestingly, among those countries where the gender gap has reversed, most are ones where women do not have the highest average levels of education (e.g., Argentina and Brazil vs. Canada and the United States). In countries like Rwanda and Guinea, where women have the lowest average levels of education, the gender gap is between 1.35 and 1.86 years of schooling. In countries where the gender gap is the highest (i.e., Uganda, Kenya and India), women's average level of education is close to four years. Moreover, even in Bolivia and Mexico, the gender gap has reversed in urban areas but still exists among the indigenous population and in rural areas (Duryea et al., 2007).

Next we examine the dynamics of the gender education gap. Figure 1c shows the gender gap in years of schooling for the age group 35-44 in the older wave of the census against the change in the gender education gap for the same age group., where the change is calculated between the most recent wave of the census and the previous one. We can observe that in the majority of countries, the gap is falling. The exception is India, where the gap is rising. As the 
second most populated country in the world, the rising gender gap in India warrants further analysis.. If we look at the change over time, we can observe the reduction in the gender gap over the course of a decade has ranged from close to 0 to -0.60 years. $^{7}$ Only Mongolia experienced a decrease in the gap greater than a year at -1.34 years, which we excluded from the graph.

\section{The Labor Force Participation Gap}

Subsequently, we examine labor force participation, where the gap is defined as the difference between the shares of men in the labor force with that of women. Figure 2a shows the gap in labor force participation in the most recent wave of the census. Rwanda is the only country where women's labor force participation is higher than men's. It is important to notice that this cohort has been affected by the 1994 genocide, which has likely affected gender roles in the household and women's labor force participation. Other African states have women’s labor force participation rates as high as those available in our sample of developed countries (Ghana, Kenya, and South Africa). Belarus exhibits equal labor force participation between men and women. Also, the other former or current communist countries (Cambodia, Romania, Mongolia, Hungary, China, and Vietnam) exhibit high female labor force participation rates and participation gaps below 20 percent. Latin American countries have higher participation gaps ranging between 29 percent in Argentina and 53 percent in Costa Rica. On the other hand, the Arab countries - Jordan, Iraq and Palestine - exhibit very large gaps above 60 percent. Among developed countries, Southern European countries (Greece, Spain and Portugal) have lower levels of women's labor force participation relative to men with respect to their Western counterparts. 
Then we examine the change in the labor-force participation gap with respect to the previous wave of the census. In Figure 2b, we plot the initial gap (horizontal axis) against the change in the gap (vertical axis). We observe heterogeneity in the change in the gap among countries that had high initial participation gaps. Brazil and Spain, which had large gaps in the 1990s, also had a reduction in the gap greater than 20 percentage points, which is the greatest among the countries in the sample. On the other hand, among countries with participation gaps above 30 percent in the initial period, Argentina, Venezuela, Israel, and Greece experienced a reduction in the gap between 10 and 20 percentage points, whereas Panama, Malaysia, India, Costa Rica, Chile, Ecuador, and Colombia had a more limited reduction in the gap, below 10 percentage points. On the other hand, Mexico experienced a widening of the participation gap. Rwanda, which already exhibited no participation gap in the early 1990s, had a further reduction in the gap. In Vietnam, Romania, South Africa, and the United States, the gap is rising, while it falls by less than 10 percentage points in the remaining countries.

Figure 2c shows that GDP and women's labor force participation follow a U-shaped curve, with women's labor force participation high (above 70 percent) in countries like Rwanda, Guinea, Ghana, and Cambodia with levels of annual GDP per capita below $\$ 1,500$. Women’s labor force participation rates are also high in countries like Austria, France, the United States, and Canada with GDP per capita above \$22,000. We also observe that most middle-income countries exhibit women's labor force participation rates below 60 percent. The level of GDP per capita at which women's labor force participation is at a minimum ${ }^{8}$ is approximately $\$ 2,800$; Iraq’s GDP per capita is close to $\$ 2,747$ in this period and women’s labor force participation is the lowest among the countries in our sample at close to 14 percent. 
Similarly, if we plot GDP per capita against the labor force participation gap (Figure 2d) we observe that the gap is lower at lower and higher levels of GDP per capita. This dynamic tends to be related to urbanization. In rural settings, women tend to participate more in production, as much of it takes place in the family farm or nearby. Urbanization increases the cost of labor force participation. Unless expected incomes are high enough to overcome the significant costs of transportation in terms of time and fees, urbanization leads to a decline in female labor force participation. ${ }^{9}$ Nevertheless, we observe that in low-income countries with high female labor force participation rates (Ghana, Guinea, Rwanda, and Uganda) the gender gap in education still exists (Figure 1a). On the other hand, in developed countries with equally high women's labor force participation rates (Canada, France, and the United States) the gender gap in education has reversed and a greater share of women are employed in high skill urban occupations.

We formalize this analysis with regressions showing the relationship between GDP and the labor force participation gap. We also examine the relationship between the labor force participation gap and the share of the population living in urban areas, as well as a measure of the rigidity of the labor market. Table 2, Column 1, shows that the log of GDP per capita and the log of GDP per capita squared are significant predictors of the gap in labor force participation, confirming the relationship suggested by the previous graph. ${ }^{10}$ Column 2 shows the regression results predicting the change in the LFP gap from the previous Census. As the earlier graphical analysis showed, the level of the gap in the previous Census is negatively related to the change in the gap, so countries with higher initial levels of the gap have decreasing gaps, indicating convergence. It also appears that the change in the LFP gap and the log of GDP per capita are positively related, also suggesting that there is a U-shaped relationship. Surprisingly, the 
regressions also show that in countries with more rigid labor markets, the gap is decreasing more, suggesting that labor market policies may have an impact on the speed at which this gap is changing, but not with the sign that is often expected. ${ }^{11}$ Finally, we see that the gap is decreasing more rapidly in countries with a greater share of the population living in urban areas. $^{12}$

\section{The Marriage Gap}

Next, we examine the gap in employment rates between married women (or women living in cohabitation) and single women, or the marriage gap ${ }^{13}$. When we plot the marriage gap against the female employment rate in Figure 3a, we see that in countries where women's employment is low (below 20 percent), the ratio of married to single women's employment rate, is low. This means that where fewer women work, fewer married women work relative to single women. The Arab countries, Palestine, Iraq and Jordan, where the marriage gap is highest, fall into this category. As the female employment rate rises, the difference in employment between married and single women decreases. There are several countries where female employment is high (above 60 percent), and married women work more than single women (Mongolia, Ghana, China, Slovenia, the UK, Hungary, Rwanda, Belarus, Canada, and Romania). We can see that these countries include both developed and developing countries, communist and former communist countries. Table 2, Column 3 shows regression results for the marriage gap. The analysis confirms the relationship between overall female labor force participation and the marriage gap. The results also show that other variables that might play a role in the marriage gap - GDP, share urban, and the rigidity of the labor market - do not significantly explain the level of the marriage gap across countries. 
In Figure 3b we present the dynamics of the marriage gap by plotting the initial marriage gap on the horizontal axis and the decade change in the gap on the vertical axis. We see that countries that started with small gaps had small changes in the marriage gap. But the picture is less clear for countries that started with large initial marriage gaps. Some countries with large initial gaps like Argentina, Brazil, and Spain had large reductions in the gap. Other countries with large initial gaps, like Chile, Ecuador, Venezuela, India, Colombia, and Panama had small reductions in the gap. Other like Costa Rica, Malaysia, and Mexico meanwhile had increases in the marriage gap.

\section{The Motherhood Gap}

Now we turn to the gap in employment among women with three children and women without children, or the motherhood gap. When we look at the ranking of countries by the motherhood gap in Figure 4a, we see that for most countries in our sample, women with children tend to work less than women without children (negative values for the motherhood gap). The gap is largest in Chile, followed by Costa Rica and Argentina. On the other hand, there are several countries with a positive motherhood gap, meaning that women with children work more than women without children. In Rwanda the difference is almost 10 percent. Interestingly, the countries with the lowest female employment rates, Iraq and Palestine, have positive motherhood gaps. n Table 2, Column 4, we show the regression results for the motherhood gap, which shows that there is no significant relationship between the motherhood gap and GDP, urbanization, the rigidity of the labor market, and the overall labor force participation of women. 
In Figure 4b we show the change in the motherhood gap across census waves vs. the initial gap. We see that countries with larger initial motherhood gaps had large changes in the gap, like in Austria, Brazil and Greece. Meanwhile, countries with positive motherhood gaps in the previous census, like China, Vietnam and South Africa, had very small changes.

\section{$\underline{\text { IX. The Relationship between the Gaps }}$}

In this section, we examine the relationships between the gaps we have discussed thus far - the gender gaps in education and labor force participation, and the marriage and motherhood gaps. In Figure 5a we plot the gender gap in education on the horizontal axis and the gender gap in labor force participation on the vertical axis. While we do not see a clear relationship between these gaps, it is evident that while the gender education gap has reversed in many countries, a labor force participation gap is still present. For example, countries like Argentina, Brazil, Colombia, the Philippines, Panama, and Venezuela, have all reversed the gender education gap, but have labor force participation gaps between 40 and 70 percent. Meanwhile, countries like China, Vietnam, and Kenya have large gender education gaps, but low labor force participation gaps. Rwanda, where women work more than men, has not reversed the gender education gap either. As discussed earlier, these patterns may be explained by greater labor force participation among low-skilled women in these countries. A country-level regression in Table 3, Column 1 shows that after controlling for other factors, the education gap in the cohort is not significantly related to the LFP gap.

In figure $5 b$ we can observe the relationship between the change in the education and labor force participation gaps. We can observe that in no country has had both gaps increase. In India, the gender gap in education has increased by 9 percent while the gender gap in labor force 
participation has decreased by around 4 percent. On the other hand, in countries like Romania, Vietnam, Mexico, South Africa, and the United States the gap in labor-force participation is increasing while the gap in education is either decreasing or remains unchanged. In the majority of countries both gaps have decreased between the oldest and newest waves of the census. The most significant reduction in the labor force participation gap has occurred in Brazil and Spain, while the greatest decrease in the education gender gap has occurred in Kenya and Malaysia. There is heterogeneity in the remaining countries Panama and Uganda for example have experienced a reduction in the labor force participation gap less than 5 percent and in the education gap of less than 10 percent, while their Israeli and Greek counterparts experienced a reduction in these two gaps of close to 20 percent and 60 percent respectively. Regression analysis (Table 3, Column 2) shows that we do not see a significant relationship between the change in the LFP gap and the change in the education gap.

Turning to the motherhood gap and the marriage gap, we see in Table 3, Columns 4 and 6, that the labor force participation gap is a significant predictor of both gaps, but the education gap is not. Thus, the reduction in gender education gap has not, in general, triggered declines in the marriage and motherhood gaps. These have responded instead to other factors that have affected the overall gap in men and women's LFP. Apart from Iraq and Palestine, there appears to be a positive relationship between these gaps; the smaller the difference in employment among married and single women, the smaller the difference between employment among women with children and women without. We imagine that many of the factors making marriage more compatible with work also tend to make motherhood more compatible with work. Column 7 in Table 3 confirms the positive relationship between these gaps after controlling for other factors. 


\section{$\underline{\text { X. Reducing the Labor Force Participation Gap: Counterfactual Analysis }}$}

Finally, we ask how much of the gender gap in labor-force participation would be reduced by eliminating the education, marriage, and motherhood gaps. We present a counterfactual analysis where we ask what the labor force participation of women would be if we gave women the average education of men, gave married women the labor force participation of otherwise equivalent single women, and gave mothers with three or more children the labor force participation of equivalent women without children (all else equal). Then we show how much of the actual gap in labor force participation between men and women is reduced given each counterfactual.

For this analysis, we ran a regression for each country using the IPUMS Census data for women age 35 to 44 . We regressed labor force participation as a function of years of schooling, age, a dummy for being married, and dummies for having children (0-6+). Then, given the estimated coefficients for women, we predicted what women's labor force participation would be if (1) they had men's level of education all other variables equal, (2) they were not married, (3) they had no children (for women with $3+$ children. Table 4 shows the results of the analysis. Column 1 shows the actual level of the gap. In Column 2, we see how much women's labor force participation would change if women had men's average level of education for countries where the gender gap has not reversed. Giving women men's level of education leads to reductions of the LFP gap of several percentage points in some African and Arab countries including Guinea, Iraq, Kenya, Palestine, and Uganda. For other countries, the reduction is

modest. Note that India is a unique case, where the LFP gap increases, which arises due to a negative relationship between education and labor force participation. 
Column 3 shows the change in the LFP gap if we eliminate the marriage gap.. For many countries, the reduction is large, particularly in Bolivia, Cambodia, Chile, Kenya, Kyrgyz Republic, Malaysia, Panama, Spain, and Venezuela. In China, Ghana, Mongolia, and Slovenia, we note that LFP gap increases in the counterfactual scenario, so marriage in these countries is associated with greater labor force-participation among women.

Next, we turn to the motherhood gap. We show in Column 4 what happens to the LFP gap when we give each mother with three or more children the LFP of an equivalent woman without children. We see that for many countries with a motherhood gap, the cells are blank because the gap actually increases in this counterfactual. In a few Latin American countries (Argentina and Chile), a couple of Arab countries (Iraq and Palestine), and Hungary, the LFP gap drops by a large amount when mothers are given the LFP of non-mothers.

Finally, in the last column we show the residual, or the share of the actual LFP gap that is not explained by the counterfactuals based on eliminating the education, marriage, and motherhood gaps. For most countries, a large share of the LFP gap remains unexplained after we eliminate these gaps. For a few countries, notably Cambodia, Chile, Hungary, Kenya, and Malaysia, less than half of the gap is left unexplained after eliminating the gaps in the other spheres, suggesting that in these countries, reducing the education, marriage, and motherhood gaps will go a significant way towards reducing the overall LFP gap. However, consistent with our previous analysis at the country level, other factors besides the education, marriage, and motherhood gaps in LFP appear to explain the lion's share of the overall gender gap in LFP for most countries. 


\section{$\underline{\text { XI. Conclusion and Discussion }}$}

The beneficial effects of educating girls and achieving gender equity in education have been prioritized by development organizations and the Millennium Development Goals. In this analysis we have documented that in many countries, the gender education gap has now closed or even reversed. However, all the countries in our samples where the gender gap has not closed are developing countries, apart from Austria. Yet, while the education gap has closed or reversed in a majority of countries, other gaps regarding women's employment, marriage, and motherhood remain. While many studies have been carried out at the national level, we have provided cross-country comparisons of these gaps. We have also documented the dynamics of the gaps and examined the importance of variables like GDP, urbanization, and labor market rigidity.

We document significant heterogeneity in terms of the size of gaps, the speed with which they are closing, and how they are inter-related. It appears that the closing of the gender education gap represents a "check in the mail” for future reductions in the gender gap in labor force participation, but does not appear to be significantly related to the gaps in employment between married and single women, and women with and without children. The differences we observe among these countries in the size of the marriage and motherhood gaps are likely related to how compatible work is with marriage and children. We show that for several countries, reductions in these gaps would reduce the overall gap in labor force participation significantly, but this would not be the case for many others.

Much of development policy aimed at achieving the MDG on gender equity has focused on reducing gender gaps in schooling through policies that change education costs or benefits (see Glick, 2008). We argue that attention should be broadened to include policies that make 
work more compatible with marriage and motherhood, which would likely increase the overall female employment and reduce the gender gap in female labor force participation. In fact, making these changes might encourage further educational investments by women. Regarding the motherhood gap, cultural attitudes, policies like availability of daycare or in-home help, urban transport, and other factors may play a role in whether women with children work, and more analysis into the impact of these factors on gender gaps is needed. Finally, it is clear that even after eliminating gaps associated with marriage and motherhood, female labor force participation seems to be low for other reasons that require further study. 


\section{REFERENCES}

Abu-Ghaida, D. and S. Klasen (2004). "The Costs of Missing the Millennium Development Goal on Gender Equity,” World Development, Volume 32, Issue 7, July 2004, Pages 1075-1107.

Attanasio O., H. Low and V. Sanchez-Marcos (2009). "Explaining Changes in Female Labour Supply in a Life-cycle Model”, American Economic Review, vol. 98(4), pp. 1517-52.

Barker, D.K. and Feiner, S.F. (2004) Liberating Economics: Feminist Perspectives on Families, Work, and Globalization. Ann Arbor: University of Michigan Press.

Becker, Gary S., (1991) A Treatise on the Family, expanded ed. (Cambridge MA: Harvard University Press).

Becker, Gary S., (1992) The Economic Way of Looking at Life, Nobel Lecture, December 9, 1992.

Becker, G. and H. G. Lewis (1973). On the Interaction Between the Quantity and Quality of Children, Journal of Political Economy, Part 2: New Economic Approaches to Fertility, 81 (2), S279--S288.

Becker, Gary S.; Murphy, Kevin M. and Tamura, Robert "Human Capital, Fertility, and Economic Growth." Journal of Political Economy, October 1990, 98(5, part 2), pp. S12-S37.

Behrman, J. and A. Deolalikar (1988) "Health and Nutrition." In Handbook of Development Economics, Vol. 1, ed. Chenery, H. and T. Srinivasan. Amstardam, North Holland: 631-704

Blau, Francine D., and Lawrence M. Kahn. 2007. "Changes in the labor supply behavior of married women: 1980-2000.” Journal of Labor Economics 25, no. 3 (July): 393-438.

Breierova, L. \& Duflo, E. (2004), 'The impact of education on fertility and child mortality: Do fathers really matter less than mothers?'. NBER Working Paper Nr.10513.

Caldwell, J. (1982). Theory of Fertility Decline. London: Academic Press.

Dancer, D., Rammohan, A. and Smith, M. D. (2008), Infant mortality and child nutrition in Bangladesh. Health Economics, 17: 1015-1035.

Duflo, Esther, Pascaline Dupas, and Michael Kremer, "Education and Fertility: Experimental Evidence from Kenya?", Draft, 2010.

Duryea S., S. Galiani, H. Ñopo and Claudia Piras (2007). "The Educational Gender Gap in Latin America and the Caribbean," RES Working Papers 4510, Inter-American Development Bank, Research Department 
Fernandez R. (2007), “Culture as Learning: The Evolution of Female Labor-Force Participation over a Century”, NBER Working Paper No. 13373

Galor O. and D.N. Weil, (1996), “The Gender Gap, Fertility, and Growth”, American Economic Review, Vol. 86, No. 3 (Jun., 1996), pp. 374-387

Glick, P., (2008). “What Policies will Reduce Gender Schooling Gaps in Developing Countries: Evidence and Interpretation,” World Development, Volume 36, Issue 9, September 2008, Pages 1623-1646.

Glewwe P. (2000). "Why does mother's schooling raise child health in developing countries? Evidence from Morocco,” Journal of Human Resources XXXIV: 124-159.

Goldin, Claudia. (1990). Understanding the gender gap: An economic history of American women. New York: Oxford University Press.

Goldin C. (1994), “The U-Shaped Female Labor Force Function in Economic Development and Economic History”, NBER Working Paper No 4707.

Goldin C. (2006), “The Quiet Revolution That Transformed Women’s Employment, Education, and Family”, American Economic Review, Vol. 96, No. 2 May, pp.1-21.

Goldin, C., L. Katz, I. Kuziemko (2006) "The Homecoming of American College Women: The Reversal of the Gender Gap in College.” Journal of Economic Perspectives 20 (Fall), pp. 133-56.

Greenwood, Jeremy; Seshadri, Ananth and Yorukoglu, Mehmet (2005). "Engines of Liberation.” Review of Economic Studies, 72(1), pp. 109-33.

Hausmann R., I. Ganguli and M. Viarengo (2009), “The Dynamics of the Gender Gap: how do Countries rank in terms of making Marriage and Motherhood compatible with Work?” in the Global Gender Gap Report 2009, Geneva: World Economic Forum Report Publication.

Heim, Bradley T. 2007. "The incredible shrinking elasticities: Married female labor supply, 1978-2002.” Journal of Human Resources 42, no. 4 (Fall): 881-918.

Huisman J. and J. Smits (2009), "Effects of Household- and District-Level Factors on Primary School Enrollment in 30 Developing Countries”, World Development, Vol.37, No.1, pp.179-193.

Juhn, C. and K.M. Murphy. "Wage inequality and family labor supply." Journal of Labor Economics 15, no. 1, part 1 (January): 72-97.

Killingsworth, M. and J. Heckman, "Female labor supply: a survey”, in Ashenfelter and Layard, (eds) Handbook of Labor Economics, Vol I, Amsterdam: North Holand, 1986. 
Kingdon G.G. (2002). “Women, Education and Development”, in Reason and Revelation:

Studies in the Babi and Baha'i Religions, 13, Los Angeles: Kalimat Press.

Lam, D. and S. Duryea. (1999). "Effects of schooling on fertility, labour supply and investments in children, with evidence from Brazil”. The Journal of Human Resources, 34(1): 160-92.

Mammen, K. and C. Paxson. (2000). “Women’s work and economic development”. Journal of Economic Perspectives, 14(4): 41-64.

McCrary, J. and H. Royer (2008). "The Effect of Female Education on Fertility and Infant Health: Evidence From School Entry Policies Using Exact Date of Birth", unpublished manuscript, Michigan University.

Mincer J., (1974) Schooling, Experience, and Earnings (New York: Columbia University Press for the National Bureau of Economic Research).

Minnesota Population Center. Integrated Public Use Microdata Series, International: Version 5.0 [Machine-readable database]. Minneapolis: University of Minnesota, 2009.

Osili, U. and B. Long (2008). “Does female schooling reduce fertility? Evidence from Nigeria,” Journal of Development Economics, Volume 87, Issue 1, August 2008, Pages 57-75.

Pritchett L. (2001), "Where Has All the Education Gone?” World Bank Economic Review, Vol.15, No.3, pp.367-391.

Pritchett L. (2006), “Does Learning to Add Up Add Up?” Handbook of Education Economics , F. Welch and E. H (eds.), Chapter 11.

Schultz, T.P. (1994). "Human capital, family planning and their effects on population growth". The American Economic Review, 84(2): 255-60.

Schultz T.P. (2002), "Why Governments Should Invest More to Educate Girls," World Development, Volume 30, Issue 2, February 2002, Pages 207-225.

Strauss J. and D. Thomas, "Human Resources: Empirical modelling of household and family decisions," in J. Behrman and T.N. Srinivasan (eds.), Handbook of Development Economics, Vol III, 1995

Sundaram A. and R. Vanneman (2008), “Gender Differentials in Literacy in India: The Intriguing Relationship with Women’s Labor Force Participation”, World Development, Vol.36, No.1, pp.128-143.

Willis, Robert J., “A New Approach to the Economic Theory of Fertility,” Journal of Political Economy, Part 2: New Economic Approaches to Fertility 1973, 81 (2), S14-S64. 
Figure 1a: Year of Birth of First Cohort where Education Gap was closed

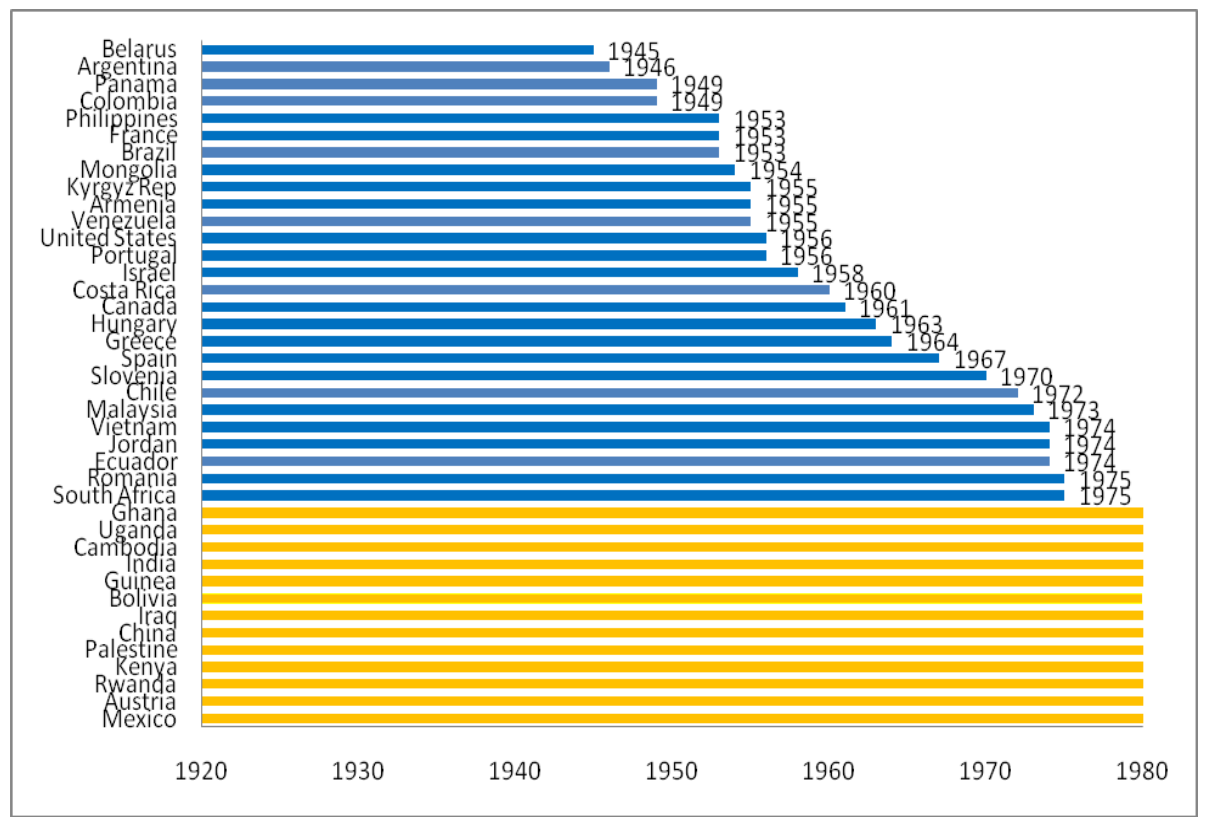

Notes: The gender education gap is calculated using the IPUMS Census data. It is calculated as the average years of education of men minus women for individuals born in a given year. The year of birth of the first cohort where the education gap was closed in the most recent available wave of the census is indicated for each country. For countries where no year is indicated, the gender gap in education has not reversed.

Figure 1b: Women's Average Years of Schooling with respect to the Gender Education Gap, most recent census wave

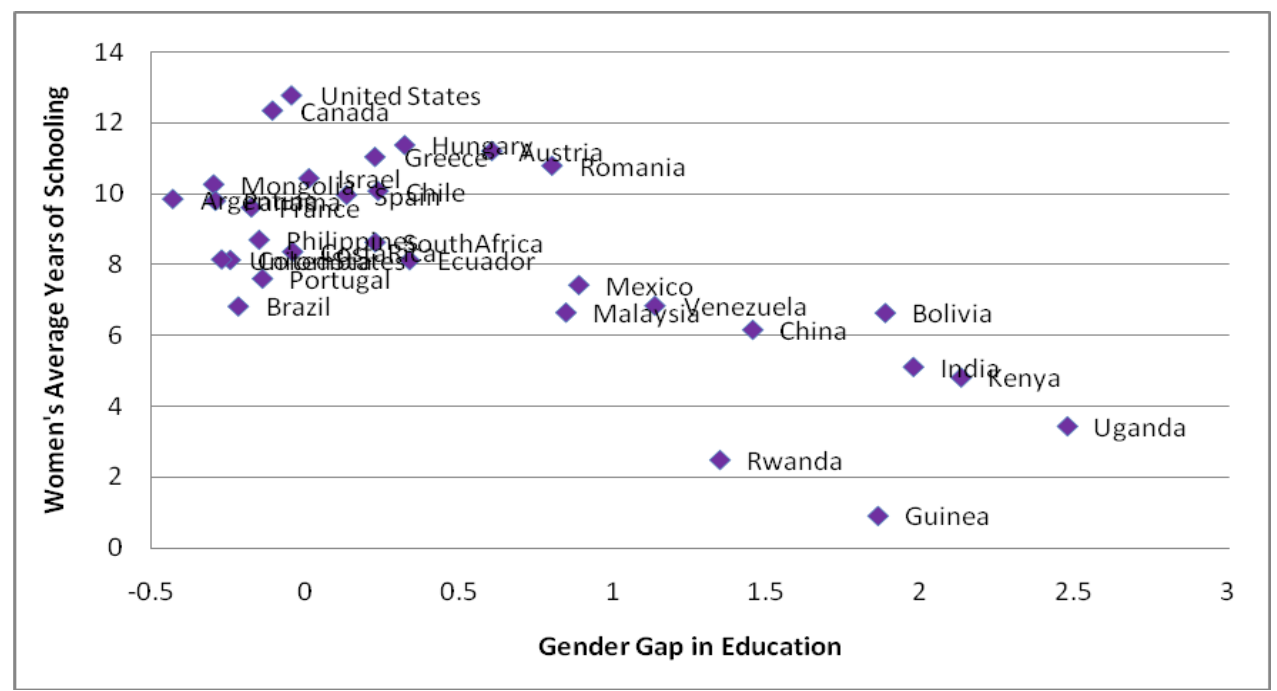

Notes: The gender education gap is calculated using the IPUMS Census data. It is defined as the average years of education of men minus women for individuals age 35-44. 
Figure 1c: Change in the Gender Education Gap with respect to the Initial Gap

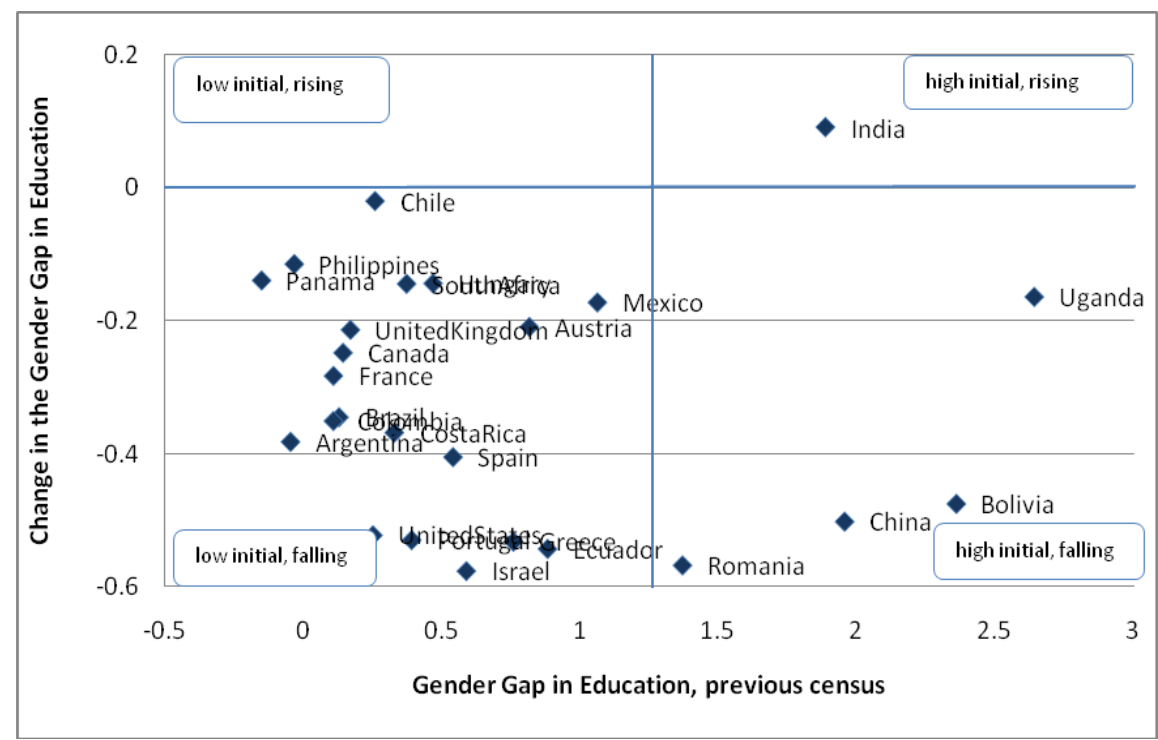

Notes: The education gap is calculated using the IPUMS Census data. It is defined as the difference in years of schooling between men and women, aged 35-44; two outliers, Guinea and Mongolia have been excluded.

\section{Figure 2a: Labor Force Participation Gap}

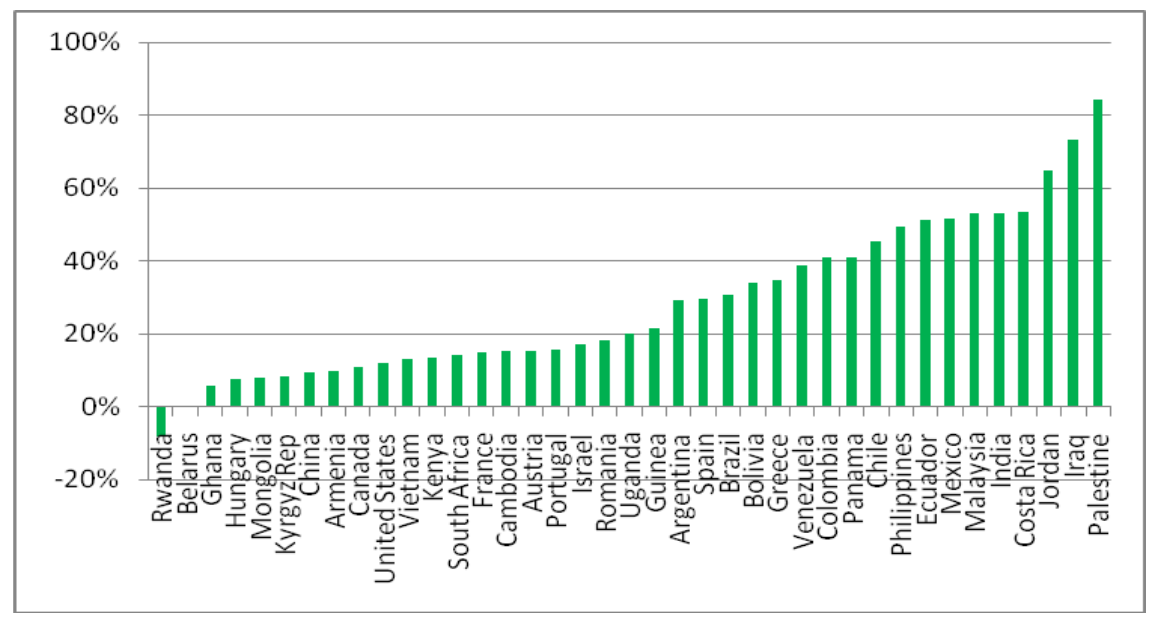

Notes: The labor force participation gap is calculated using the IPUMS Census data. It is defined as the share of men in the labor force (employed or unemployed and job seeking) minus women in the labor force for individuals age 35-44. 
Figure 2b: Change in the Gender Labor Force Participation Gap with respect to the Initial Gap

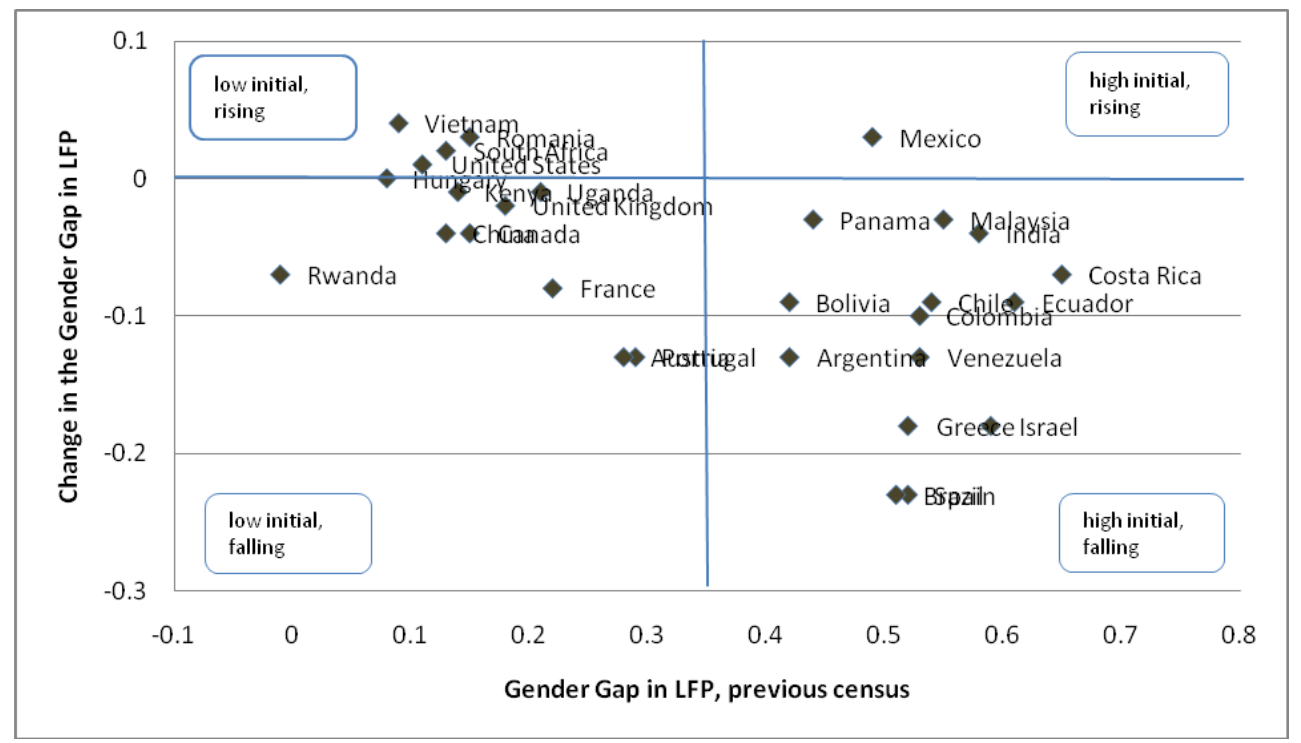

Notes: The labor force participation gap is calculated using the IPUMS Census data. It is defined as the share of men in the labor force minus women in the labor force for individuals age 35-44.

Figure 2c: Women's Labor Force Participation vs. GDP per capita, PPP

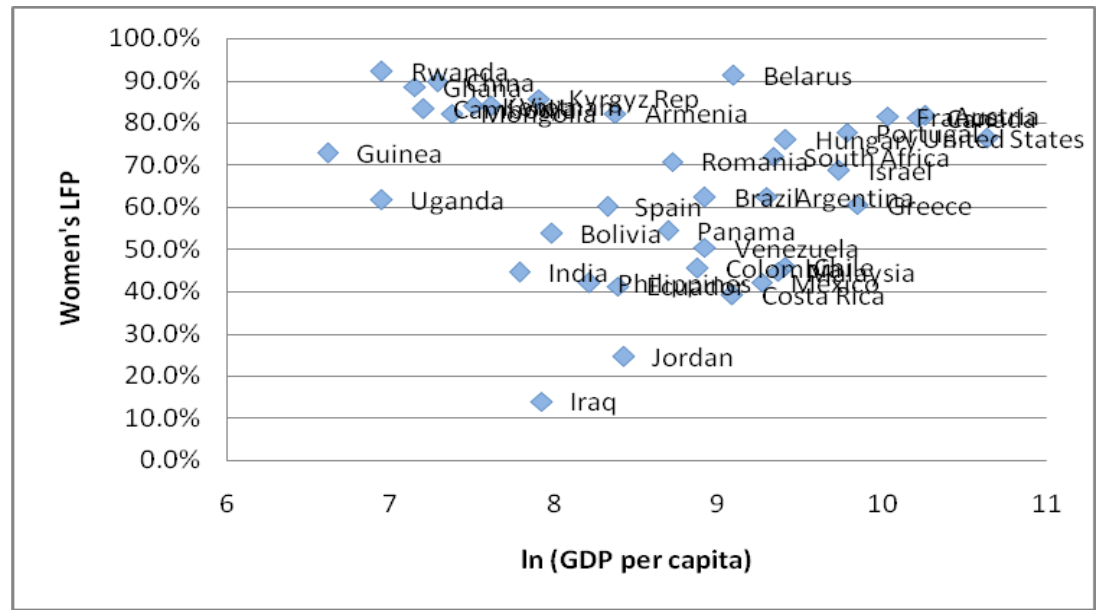

Note: GDP data comes from the World Development indicators. Women's labor force participation is calculated using the IPUMS Census data. It is defined as the measure of the total number of women working or seeking work age 35-44 as a share of all women 35-44. 


\section{Figure 2d: Labor Force Participation Gap vs. GDP per capita, PPP}

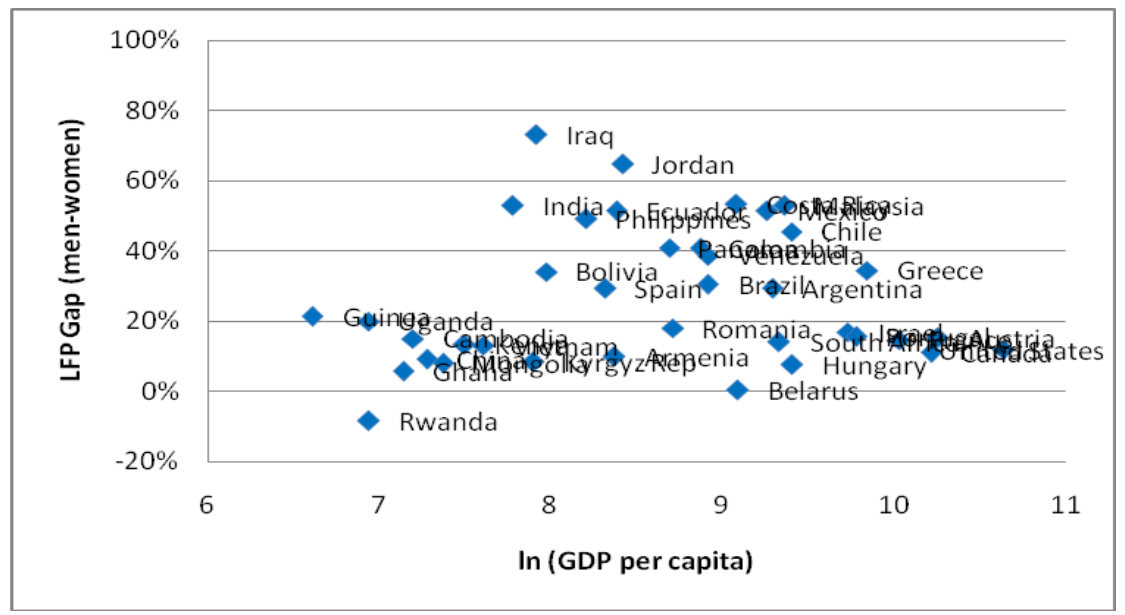

Notes: GDP data comes from the World Development indicators. The labor force participation gap is calculated using the IPUMS Census data. The labor force participation gap calculated as the share of men in the labor force minus women in the labor force for individuals age 35-44.

\section{Figure 2e. Labor Force Participation Gap vs. Share of Urban Population}

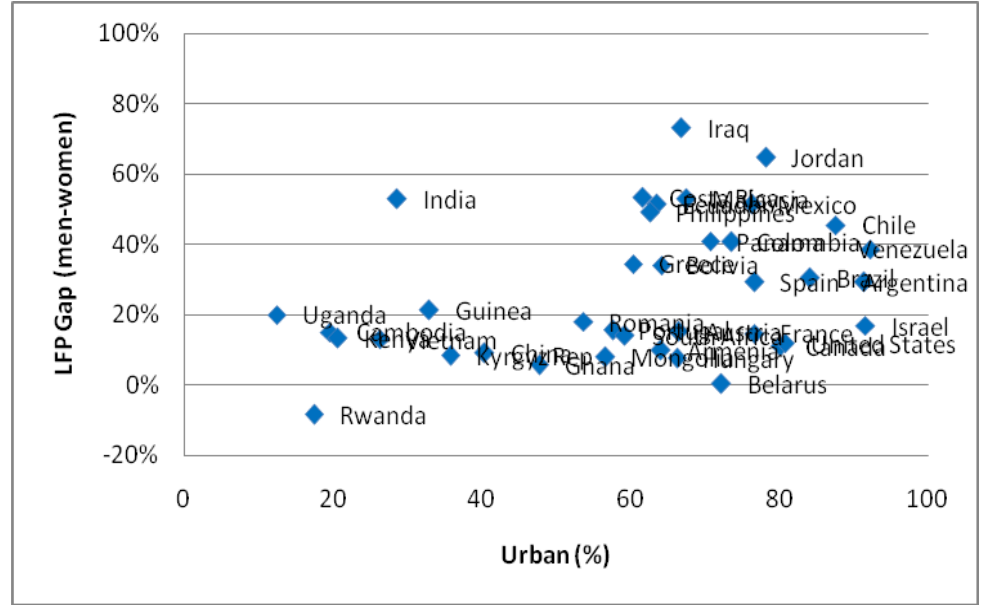

Notes: The share of the population living in urban areas data comes from the World Development indicators. The labor force participation gap is calculated using the IPUMS Census data. The labor force participation gap calculated as the share of men in the labor force minus women in the labor force for individuals age $35-44$. 


\section{Figure 3a: Ratio of Married to Single Women Employment Rate}

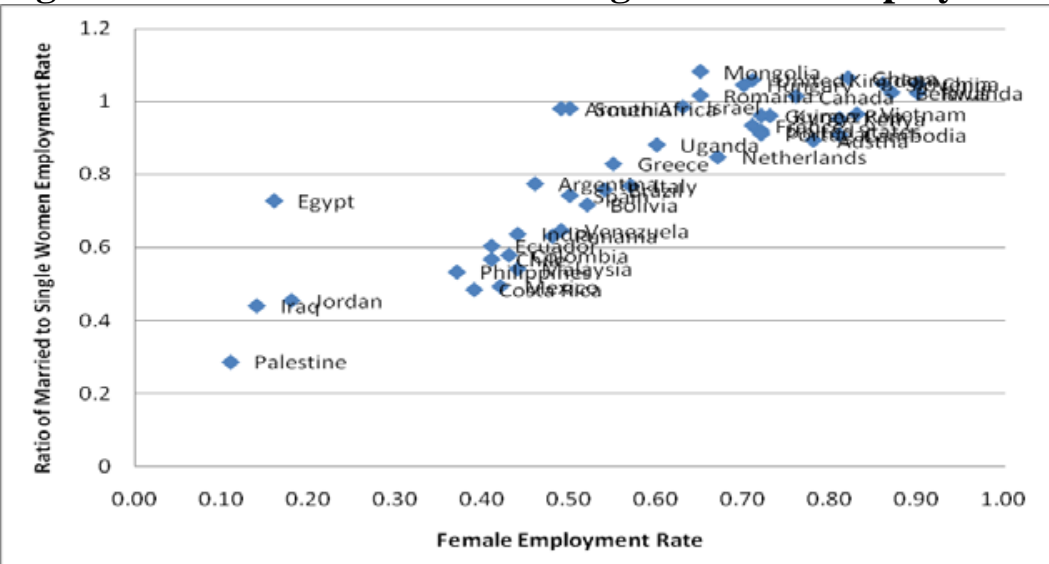

Note: Measures constructed from the IPUMS Census data. The marriage gap is the difference in employment between single and married women aged 35-44.

Figure 3b: Change in the Marriage Gap vs. Initial Gap

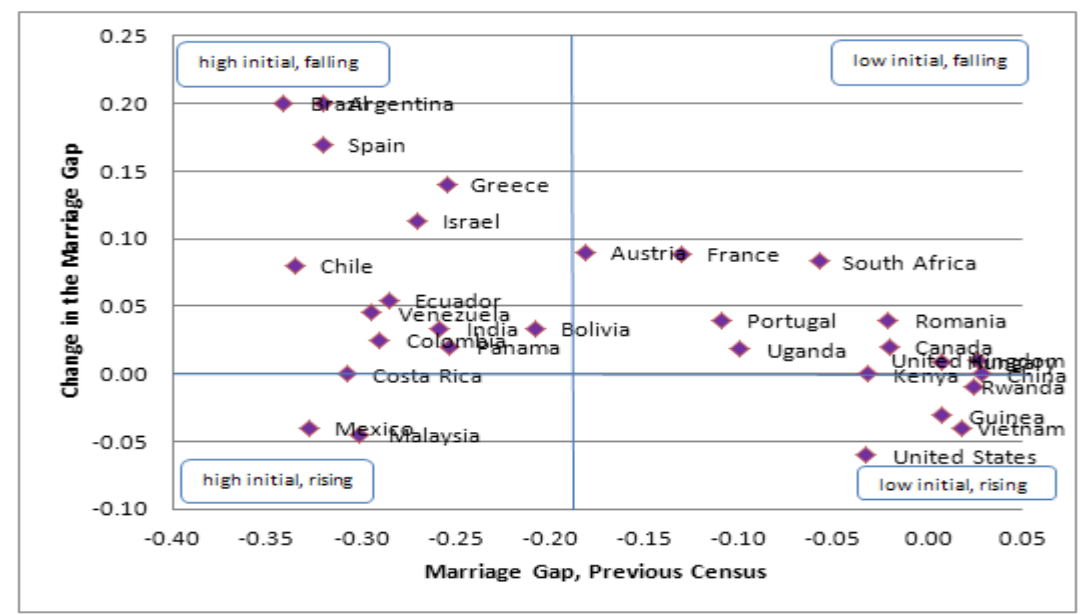

Note: Measures constructed from the IPUMS Census data. The marriage gap is the difference in employment between single and married women aged 35-44. The change in the marriage gap is the percentage change in marriage gap between the last two censuses, for women aged 35-44. 
Figure 4a: Motherhood Gap, most recent wave

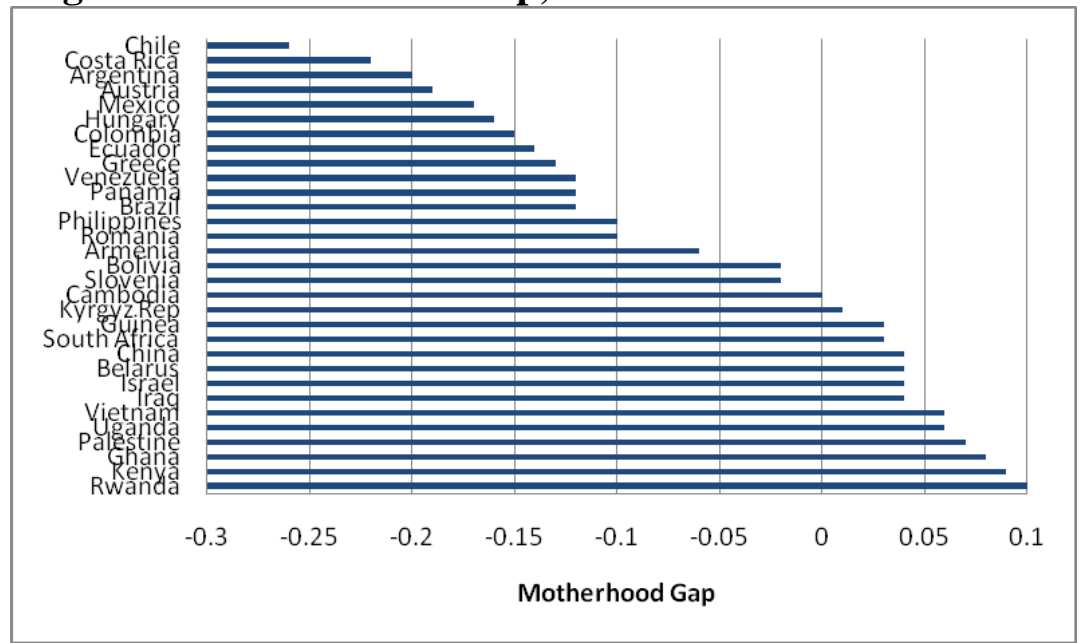

Notes: Measure constructed from the IPUMS Census data. The motherhood gap is the share of women with three children working minus the share of women with no children working for women aged 35-44.

\section{Figure 4b: Change in the Motherhood gap vs. the Initial Gap}

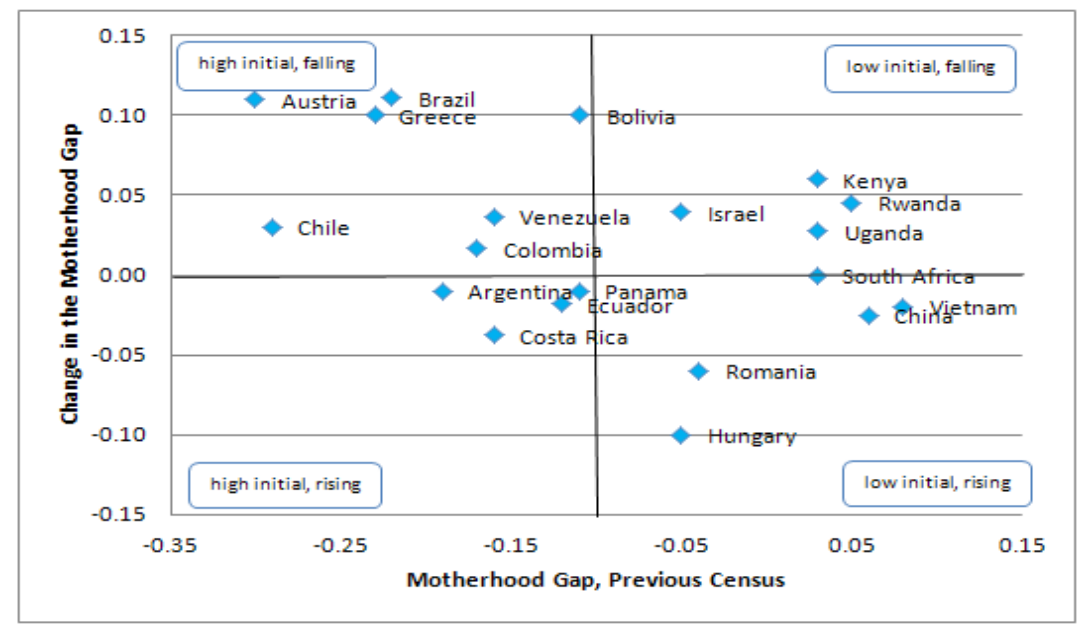

Notes: Measure constructed from the IPUMS Census data. The motherhood gap is the share of women with three children working minus the share of women with no children working for women aged 35-44. 
Figure 5a: Gender Gap in Education vs. Gender Gap in Labor Force Participation

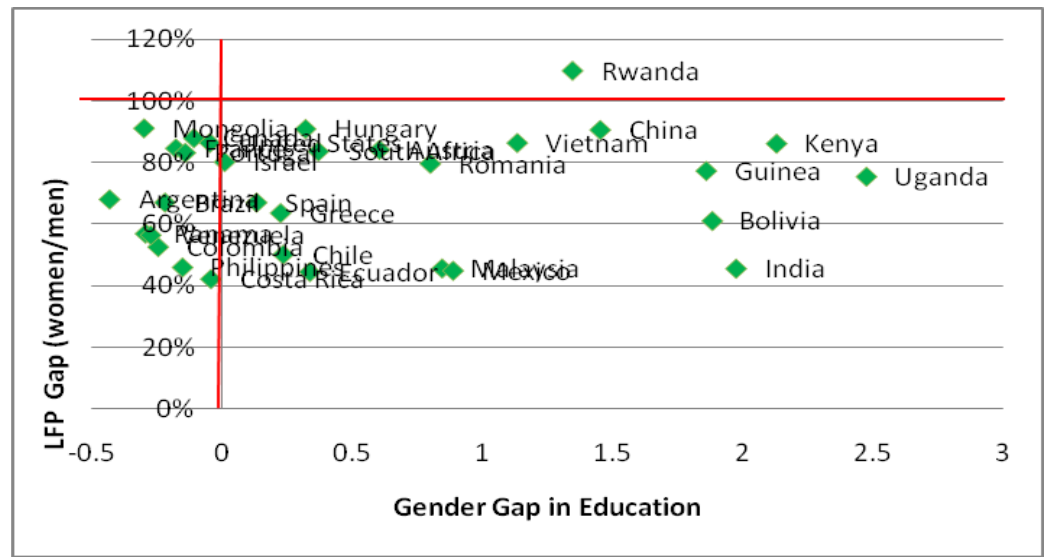

Notes: Measure constructed from the IPUMS Census data. The gender education gap is the difference between men's and women's years of schooling for men and women aged 35-44. The labor force participation gap is calculated as the share of men in the labor force divided by the share of women in the labor force for individuals age 35-44.

Figure 5b: Change in Gender Gap in Education vs. Change in Gender Gap in Labor Force Participation

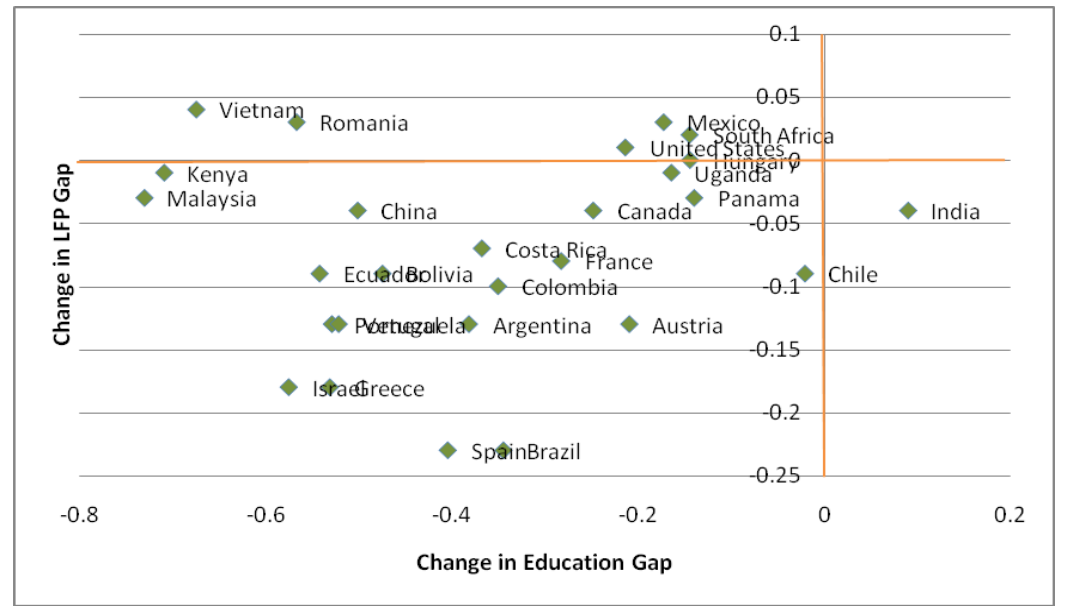

Notes: Measure constructed from the IPUMS Census data. The gender education gap is the difference between men's and women's years of schooling for men and women aged 35-44. The labor force participation gap calculated as the share of men in the labor force minus women in the labor force for individuals age 35-44. This graph is presented for those countries for which we have information on both the gender and the labor force participation gaps. 
Figure 5c: Motherhood Gap vs. Marriage Gap

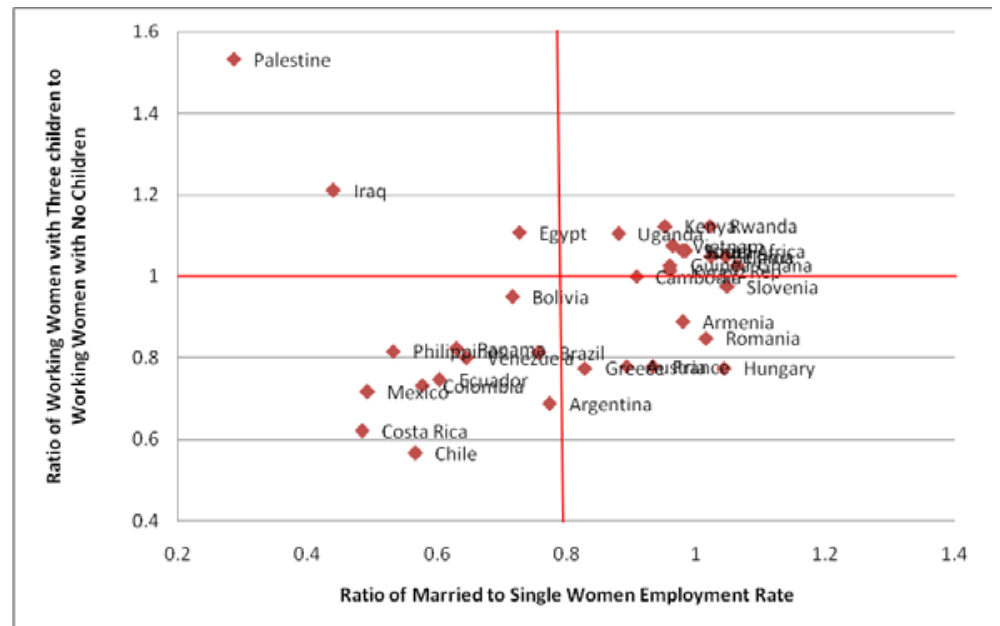

Notes: Measure constructed from the IPUMS Census data. The motherhood gap is the share of women with three children working minus the share of women with no children working for women aged 35-44. The marriage gap is the difference in employment between single and married women aged 35-44. 
Table 1. The Reversal of the Gender Education Gap

\begin{tabular}{|c|c|c|}
\hline Country & $\begin{array}{l}\text { Birth year of cohort in which } \\
\text { gap reversed }\end{array}$ & $\begin{array}{c}\text { Gap in years of } \\
\text { schooling at age } 25\end{array}$ \\
\hline Belarus & 1945 & -0.4 \\
\hline Argentina & 1946 & -0.8 \\
\hline Colombia & 1949 & -0.7 \\
\hline Panama & 1949 & -0.6 \\
\hline Brazil & 1953 & -0.8 \\
\hline France & 1953 & -0.7 \\
\hline Philippines & 1953 & -0.6 \\
\hline Mongolia & 1954 & -1.2 \\
\hline Venezuela & 1955 & -0.9 \\
\hline Armenia & 1955 & -0.5 \\
\hline Kyrgyz Rep & 1955 & -0.1 \\
\hline Portugal & 1956 & -1.0 \\
\hline United States & 1956 & 0.0 \\
\hline Israel & 1958 & -0.1 \\
\hline Costa Rica & 1960 & -0.4 \\
\hline Canada & 1961 & -0.5 \\
\hline Hungary & 1963 & -0.3 \\
\hline Greece & 1964 & -0.8 \\
\hline Spain & 1967 & -0.7 \\
\hline Slovenia & 1970 & -0.6 \\
\hline Chile & 1972 & -0.1 \\
\hline Malaysia & 1973 & -0.2 \\
\hline Ecuador & 1974 & -0.3 \\
\hline Jordan & 1974 & -0.2 \\
\hline Vietnam & 1974 & 0.0 \\
\hline South Africa & 1975 & -0.4 \\
\hline Romania & 1975 & -0.1 \\
\hline Mexico & & 0.1 \\
\hline Austria & & 0.1 \\
\hline Rwanda & & 0.6 \\
\hline Kenya & & 0.6 \\
\hline Palestine & & 0.8 \\
\hline China & & 0.8 \\
\hline Iraq & & 1.1 \\
\hline Bolivia & & 1.2 \\
\hline Guinea & & 1.3 \\
\hline India & & 1.5 \\
\hline Cambodia & & 1.6 \\
\hline Uganda & & 1.6 \\
\hline Ghana & & 2.1 \\
\hline
\end{tabular}

Notes: The United Kingdom has been excluded as data is missing for the individuals age 25. 
Table 2. Gender Gap Regressions

\begin{tabular}{lllll}
\hline & $(1)$ & $\begin{array}{l}(2) \\
\text { Change in } \\
\text { LFP Gap }\end{array}$ & $\begin{array}{l}\text { (3) } \\
\text { Marriage } \\
\text { Gap }\end{array}$ & $\begin{array}{l}(4) \\
\text { Motherhood } \\
\text { Gap }\end{array}$ \\
\hline Log GDP & $\begin{array}{l}1.146^{* *} \\
(0.537)\end{array}$ & $\begin{array}{l}0.801^{* * *} \\
(0.261)\end{array}$ & $\begin{array}{l}-0.700 \\
(0.710)\end{array}$ & $\begin{array}{l}-0.228 \\
(0.554)\end{array}$ \\
Log GDP- & & & & \\
Squared & $-0.0685^{* *}$ & $-0.0442^{* * *}$ & 0.0434 & 0.00805 \\
Rigidity of & $(0.0305)$ & $(0.0149)$ & $(0.0412)$ & $(0.0323)$ \\
Employment & & & & \\
Index & -0.000105 & $-0.00158^{* *}$ & -0.00153 & 0.000740 \\
Share Urban & 0.287 & $(0.000705)$ & $(0.00243)$ & $(0.00191)$ \\
LFP Gap, & $(0.217)$ & $-0.232^{* *}$ & -0.422 & -0.0521 \\
Previous & & $(0.0922)$ & $(0.260)$ & $(0.216)$ \\
Census & & & & \\
Women's & & $-0.223^{* *}$ & & \\
LFP & & $(0.0794)$ & & $(0.165)$ \\
\hline Constant & $-4.613^{* *}$ & $-3.365^{* * *}$ & 3.907 & $(2.329)$ \\
\hline
\end{tabular}

Standard errors in parentheses

$* * * \mathrm{p}<0.01, * * \mathrm{p}<0.05, * \mathrm{p}<0.1$

Notes: Regressions are based on the gender gap measures described in the data section. GDP per capita and level of urbanization come from the World Development Indicators. The Rigidity of Employment Index ( $0=$ less rigid, $100=$ more rigid) comes from the World Bank's “Doing Business" dataset. This index measures the regulation of employment, specifically the hiring and firing of workers and the rigidity of working hours. It is the average of three indexes: a difficulty of hiring index, a rigidity of hours index, and a difficulty of firing index. The results do not change when including Share of Urban-Squared. 
Table 3. Regressions Showing the Relationship Between Gaps

\begin{tabular}{|c|c|c|c|c|c|c|c|}
\hline & $\begin{array}{l}\text { (1) } \\
\text { LFP Gap }\end{array}$ & $\begin{array}{l}(2) \\
\text { Change in } \\
\text { LFP Gap }\end{array}$ & $\begin{array}{l}(3) \\
\text { Marriage } \\
\text { Gap }\end{array}$ & $\begin{array}{l}(4) \\
\text { Marriage } \\
\text { Gap }\end{array}$ & $\begin{array}{l}(5) \\
\text { Motherhood } \\
\text { Gap }\end{array}$ & $\begin{array}{l}(6) \\
\text { Motherhood } \\
\text { Gap }\end{array}$ & $\begin{array}{l}(7) \\
\text { Motherhood } \\
\text { Gap }\end{array}$ \\
\hline Log GDP & $\begin{array}{l}1.535^{* * *} \\
(0.532)\end{array}$ & $\begin{array}{l}0.386 \\
(0.399)\end{array}$ & $\begin{array}{l}-0.215 \\
(0.268)\end{array}$ & $\begin{array}{l}-0.0154 \\
(0.371)\end{array}$ & $\begin{array}{l}-0.198 \\
(0.540)\end{array}$ & $\begin{array}{l}-0.00976 \\
(0.501)\end{array}$ & $\begin{array}{l}-0.0421 \\
(0.495)\end{array}$ \\
\hline $\begin{array}{l}\text { Log GDP- } \\
\text { Squared }\end{array}$ & $\begin{array}{l}-0.0894 * * * \\
(0.0303)\end{array}$ & $\begin{array}{l}-0.0202 \\
(0.0222)\end{array}$ & $\begin{array}{l}0.0125 \\
(0.0156)\end{array}$ & $\begin{array}{l}0.00239 \\
(0.0214)\end{array}$ & $\begin{array}{l}0.00617 \\
(0.0314)\end{array}$ & $\begin{array}{l}-0.00310 \\
(0.0288)\end{array}$ & $\begin{array}{l}-0.00175 \\
(0.0285)\end{array}$ \\
\hline $\begin{array}{l}\text { Rigidity of } \\
\text { Employment }\end{array}$ & & & & & & & \\
\hline Index & $\begin{array}{l}-0.000632 \\
(0.00174)\end{array}$ & $\begin{array}{l}-0.000482 \\
(0.000814)\end{array}$ & $\begin{array}{l}0.000852 \\
(0.000929)\end{array}$ & $\begin{array}{l}0.000935 \\
(0.00128)\end{array}$ & $\begin{array}{l}0.00100 \\
(0.00187)\end{array}$ & $\begin{array}{l}0.000307 \\
(0.00172)\end{array}$ & $\begin{array}{l}-0.000126 \\
(0.00172)\end{array}$ \\
\hline Share Urban & $\begin{array}{l}0.287 \\
(0.246)\end{array}$ & $\begin{array}{l}-0.336 * * * \\
(0.108)\end{array}$ & $\begin{array}{l}0.00282 \\
(0.103)\end{array}$ & $\begin{array}{l}0.0205 \\
(0.168)\end{array}$ & $\begin{array}{l}-0.0309 \\
(0.208)\end{array}$ & $\begin{array}{l}0.0408 \\
(0.227)\end{array}$ & $\begin{array}{l}0.00642 \\
(0.220)\end{array}$ \\
\hline Education & & & & & & & \\
\hline Gap & $\begin{array}{l}0.0739 \\
(0.0566)\end{array}$ & & & $\begin{array}{l}0.0459 \\
(0.0441)\end{array}$ & & $\begin{array}{l}0.0539 \\
(0.0595)\end{array}$ & $\begin{array}{l}0.0322 \\
(0.0593)\end{array}$ \\
\hline $\begin{array}{l}\text { Change in } \\
\text { Education Gap }\end{array}$ & & $\begin{array}{l}-0.0173 \\
(0.0622)\end{array}$ & & & & & \\
\hline LFP Gap & & & $\begin{array}{l}-0.985^{* * *} \\
(0.0823)\end{array}$ & $\begin{array}{l}-0.989 * * * \\
(0.159)\end{array}$ & $\begin{array}{l}-0.283 \\
(0.166)\end{array}$ & $\begin{array}{l}-0.500^{* *} \\
(0.215)\end{array}$ & \\
\hline $\begin{array}{l}\text { Marriage } \\
\text { Gap }\end{array}$ & & & & & & & $\begin{array}{l}0.444 * * \\
(0.189)\end{array}$ \\
\hline Constant & $\begin{array}{l}-6.422^{* * *} \\
(2.238)\end{array}$ & $\begin{array}{l}-1.668 \\
(1.707)\end{array}$ & $\begin{array}{l}1.955^{*} \\
(1.112)\end{array}$ & $\begin{array}{l}0.954 \\
(1.576)\end{array}$ & $\begin{array}{l}1.187 \\
(2.242)\end{array}$ & $\begin{array}{l}0.247 \\
(2.124)\end{array}$ & $\begin{array}{l}-0.0191 \\
(2.149)\end{array}$ \\
\hline Observations & 27 & 22 & 28 & 19 & 28 & 19 & 19 \\
\hline R-squared & 0.425 & 0.505 & 0.907 & 0.865 & 0.518 & 0.751 & 0.753 \\
\hline
\end{tabular}

Notes: Standard errors in parentheses, ${ }^{* * *} \mathrm{p}<0.01,{ }^{* *} \mathrm{p}<0.05,{ }^{*} \mathrm{p}<0.1$. Regressions are based on the gender gap measures described in the data section. GDP per capita and level of urbanization come from the World Development Indicators. The Rigidity of Employment Index ( $0=$ less rigid, $100=$ more rigid) comes from the World Bank’s “Doing Business” dataset. The results do not change when including Share of Urban-Squared. 
Table 4. Counterfactual Participation Gap Analysis

\begin{tabular}{|c|c|c|c|c|c|}
\hline Census Wave & $\begin{array}{c}\text { (1) } \\
\text { Actual LFP } \\
\text { Gap }\end{array}$ & $\begin{array}{c}\text { (2) } \\
\text { Gap w/o } \\
\text { Education Gap }\end{array}$ & $\begin{array}{c}\text { (3) } \\
\text { Gap w/o } \\
\text { Marriage Gap }\end{array}$ & $\begin{array}{c}\text { (4) } \\
\text { Gap w/o } \\
\text { Motherhood Gap }\end{array}$ & $\begin{array}{c}\text { (5) } \\
\text { Residual (\% of } \\
\text { Actual Gap) }\end{array}$ \\
\hline Argentina 2001 & 29.17 & - & 19.61 & 25.95 & $56 \%$ \\
\hline Armenia 2001 & 9.88 & - & 6.94 & - & $70 \%$ \\
\hline Belarus 1999 & 0.28 & - & - & - & \\
\hline Bolivia 2001 & 34.12 & 33.61 & 20.51 & - & $59 \%$ \\
\hline Brazil 2000 & 29.96 & - & 19.04 & - & $64 \%$ \\
\hline Cambodia 1998 & 14.23 & 14.93 & 5.54 & - & $44 \%$ \\
\hline Canada 2001 & 10.85 & - & 9.62 & - & $89 \%$ \\
\hline Chile 2002 & 45.48 & 45.04 & 26.36 & 38.33 & $41 \%$ \\
\hline China 1990 & 9.27 & 8.81 & - & - & $95 \%$ \\
\hline Colombia 2005 & 30.81 & - & 25.15 & - & $82 \%$ \\
\hline $\begin{array}{l}\text { Costa Rica } \\
2000\end{array}$ & 53.38 & - & 31.34 & 52.37 & $57 \%$ \\
\hline Ecuador 2001 & 51.25 & 50.26 & 34.79 & - & $66 \%$ \\
\hline Ghana 2000 & 5.74 & 5.58 & - & - & $97 \%$ \\
\hline Greece 2001 & 34.5 & 33.8 & 23.55 & 34.28 & $66 \%$ \\
\hline Guinea 1996 & 21.37 & 18.7 & 16.43 & - & $64 \%$ \\
\hline Hungary 2001 & 7.55 & 7.09 & 7.17 & 3.99 & $42 \%$ \\
\hline India 1999 & 52.89 & - & 34.57 & - & $65 \%$ \\
\hline Iraq 1997 & 73.21 & 62.91 & 65.62 & 67.55 & $68 \%$ \\
\hline Israel 1995 & 16.94 & 16.8 & 12.96 & - & $76 \%$ \\
\hline Jordan 2004 & 64.87 & 62.54 & 41.22 & - & $60 \%$ \\
\hline Kenya 1999 & 13.38 & 11.07 & 7.31 & - & $37 \%$ \\
\hline $\begin{array}{l}\text { Kyrgyz Rep } \\
1999\end{array}$ & 8.39 & - & 3.34 & - & $40 \%$ \\
\hline Malaysia 2000 & 52.91 & 51.45 & 19.8 & - & $35 \%$ \\
\hline Mongolia 2000 & 7.89 & - & - & - & \\
\hline Palestine 1997 & 84.15 & 79.11 & 70.86 & 74.53 & $67 \%$ \\
\hline Panama 2000 & 40.96 & - & 24.04 & 39.85 & $56 \%$ \\
\hline Portugal 2001 & 15.63 & - & 12.13 & & $78 \%$ \\
\hline Romania 2002 & 18.02 & 16.22 & 17.04 & 16.17 & $74 \%$ \\
\hline Rwanda 2002 & - & - & - & - & \\
\hline Slovenia 2002 & 3.44 & 3.26 & - & - & $95 \%$ \\
\hline Spain 2001 & 29.38 & - & 16.73 & - & $57 \%$ \\
\hline Uganda 2002 & 20.02 & 17.25 & 13.75 & - & $55 \%$ \\
\hline US 2005 & 15.74 & - & 9.48 & - & $60 \%$ \\
\hline $\begin{array}{l}\text { Venezuela } \\
2001\end{array}$ & 38.66 & - & 21.98 & 37.75 & $55 \%$ \\
\hline Vietnam 1999 & 13.58 & 13.82 & 7.47 & - & $57 \%$ \\
\hline
\end{tabular}

Notes: (1) is the labor force participation gap calculated as the share of men in the labor force minus women in the labor force for individuals age 35-44. For (2)-(4), a counterfactual gap is calculated based on a regression of women's labor force participation as a function of years of education, age, dummy for married and dummies for children (0-6+). Then, we predict women's labor force participation if they had men's level of education all other variables equal in (2); if they if they did not have "marriage gap" all 
other variables equal (omitted coefficient on marriage) in (3); if they did not have a "Motherhood gap" all other variables equal (omitted coefficients for children $3+$ ) in (4). (5) is the share of the actual gap left after subtracting (2)-(4) from the actual gap. If a cell is blank, the relevant gap has reversed or is 0, or increases the LFP gap, which is noted in the text. In some cases a cell is blank because variables are missing, i.e. the number of children ever born: not available for Canada, India, Jordan, Mongolia, Portugal, Spain, Uganda, United States; Labor force participation: not available for Mexico. 


\section{APPENDIX}

$\underline{\text { Table A1. Analytic Samples }}$

\begin{tabular}{|c|c|c|}
\hline Country & $\begin{array}{c}\text { Sample } 1 \\
\text { Waves of the Census }\end{array}$ & $\begin{array}{c}\text { Sample } 2 \\
\text { Waves of the Census }\end{array}$ \\
\hline Argentina & 2001 & 1991, 2001 \\
\hline Armenia & 2001 & \\
\hline Austria & 2001 & 1991, 2001 \\
\hline Belarus & 1999 & \\
\hline Bolivia & 2001 & 1992, 2001 \\
\hline Brazil & 2000 & 1991, 2000 \\
\hline Cambodia & 1998 & \\
\hline Canada & 2001 & 1991, 2001 \\
\hline Chile & 2002 & 1992, 2002 \\
\hline China & 1990 & 1982, 1990 \\
\hline Colombia & 2005 & 1993, 2005 \\
\hline Costa Rica & 2000 & 1984, 2000 \\
\hline Ecuador & 2001 & 1990, 2001 \\
\hline France & 1999 & 1990, 1999 \\
\hline Ghana & 2000 & \\
\hline Greece & 2001 & 1991, 2001 \\
\hline Guinea & 1996 & \\
\hline Hungary & 2001 & 1990, 2001 \\
\hline India & 1999 & 1987, 1999 \\
\hline Iraq & 1997 & \\
\hline Israel & 1995 & 1972, 1995 \\
\hline Jordan & 2004 & \\
\hline Kenya & 1999 & 1989, 1999 \\
\hline Kyrgyz Rep & 1999 & \\
\hline Malaysia & 2000 & 1991, 2000 \\
\hline Mexico & 2005 & 1995, 2005 \\
\hline Mongolia & 2000 & \\
\hline Palestine & 1997 & \\
\hline Panama & 2000 & 1990, 2000 \\
\hline Philippines & 2000 & \\
\hline Portugal & 2001 & 1991, 2001 \\
\hline Romania & 2002 & 1992, 2002 \\
\hline Rwanda & 2002 & 1991, 2002 \\
\hline Slovenia & 2002 & \\
\hline South Africa & 2007 & 2001, 2007 \\
\hline Spain & 2001 & 1991, 2001 \\
\hline Uganda & 2002 & 1991, 2002 \\
\hline United Kingdom & 2001 & 1991, 2001 \\
\hline United States & 2005 & 2000, 2005 \\
\hline Venezuela & 2001 & 1990, 2001 \\
\hline Vietnam & 1999 & 1989, 1999 \\
\hline
\end{tabular}


Table A2. Women's LFP Regressions

\begin{tabular}{|c|c|c|c|c|}
\hline & (1) & (2) & (3) & (4) \\
\hline & $\begin{array}{l}\text { Women's } \\
\text { LFP }\end{array}$ & $\begin{array}{l}\text { Women's } \\
\text { LFP }\end{array}$ & $\begin{array}{l}\text { Women's } \\
\text { LFP }\end{array}$ & $\begin{array}{l}\text { Women's } \\
\text { LFP }\end{array}$ \\
\hline \multirow[t]{2}{*}{ Log GDP } & $-1.506^{* * *}$ & $\begin{array}{l}-1.070^{* *} \\
\end{array}$ & $-1.096^{* *}$ & $-1.127^{*}$ \\
\hline & $(0.444)$ & $(0.500)$ & $(0.526)$ & $(0.559)$ \\
\hline \multirow[t]{2}{*}{$\begin{array}{l}\text { Log GDP- } \\
\text { Squared }\end{array}$} & $0.0868 * * *$ & $0.0647^{* *}$ & 0.0661** & $0.0680^{* *}$ \\
\hline & $(0.0258)$ & \begin{tabular}{|l|}
$(0.0282)$ \\
\end{tabular} & $(0.0296)$ & $(0.0316)$ \\
\hline \multirow[t]{2}{*}{ Share Urban } & & $-0.368 *$ & -0.241 & -0.247 \\
\hline & & $(0.213)$ & $(0.712)$ & $(0.723)$ \\
\hline \multirow[t]{2}{*}{$\begin{array}{l}\text { Share Urban- } \\
\text { Squared }\end{array}$} & & & -0.112 & -0.106 \\
\hline & & & $(0.600)$ & $(0.610)$ \\
\hline \multirow[t]{2}{*}{$\begin{array}{l}\text { Rigidity of } \\
\text { Employment } \\
\text { Index }\end{array}$} & & & & 0.000353 \\
\hline & & & & $(0.00187)$ \\
\hline \multirow[t]{2}{*}{ Constant } & $7.086^{* * *}$ & \begin{tabular}{|l|}
$5.216 * *$ \\
\end{tabular} & $5.301 * *$ & $5.416^{* *}$ \\
\hline & (1.884) & (2.130) & $(2.208)$ & $(2.324)$ \\
\hline Observations & 38 & 38 & 38 & 38 \\
\hline R-squared & 0.251 & 0.311 & 0.312 & 0.313 \\
\hline
\end{tabular}

Notes: Standard errors in parentheses, ${ }^{* * *} \mathrm{p}<0.01,{ }^{* *} \mathrm{p}<0.05$, ${ }^{*} \mathrm{p}<0.1$. Regressions are based on the gender gap measures described in the data section. GDP per capita and level of urbanization come from the World Development Indicators. The Rigidity of Employment Index ( $0=$ less rigid, $100=$ more rigid) comes from the World Bank’s Doing Business dataset. 
$\underline{\text { Notes }}$

${ }^{1}$ Art. 26: "Everyone has the right to education. [...] and higher education shall be equally accessible to all on the basis of merit.... Education shall be directed to the full development of the human personality and to the strengthening of respect for human rights...."

${ }^{2}$ At the macro-level, cross-country evidence linking education to growth has not reached definitive conclusions (Pritchett 2001, 2006). Among the factors that may explain the discrepancy between macro and micro analyses are measurement error in macro regressions and issues related to the quality of education.

${ }^{3}$ We acknowledge the possible multidimensionality of gender inequalities. Sundaram and Vanneman (2008) found that in Indian districts where there is a higher share of women in the girls literacy is further behind boys' literacy and explain this fact by suggesting that in this context where more mothers work outside the household more girls have to work to help the family. Moreover, it would be important to examine women's participation by sector with a focus on the employment-status categories. Due to data limitations it has not been possible here (in this regard, an interesting analysis has been carried out for India by Huisman and Smits, 2009).

${ }^{4}$ We acknowledge the existence of a U-shaped curve for married women's participation as documented by Goldin (1994). That is, when women are poorly educated they are employed in low-skill, often manual activities with which a social stigma exists, but when they are educated, however, they find employment in more socially acceptable labor market activities.

${ }^{5}$ In some parts of the analysis we define the labor force participation gap as the ratio of the shares, as noted.

${ }^{6}$ See Table A1 in the appendix for a description of the analytic sample (1).

${ }^{7}$ Over the period considered, which is the difference between the two census waves. See Table A, which shows the sample for each country.

${ }^{8}$ This observation is supported by regression analysis using the specification in Appendix Table A2.

${ }^{9}$ Table A2 provides evidence that the relationship between female labor force participation and GDP per capita is weaker after controlling for urbanization.

${ }^{10}$ Including urban-squared in the regression does not change the results.

${ }^{11}$ The mean of the Rigidity Employment Index is 37.9 and the standard deviation is 16.9. An increase in the Rigidity Employment Index of one standard deviation would lead to a reduction in the gap by 0.027 percent, so the effect is relatively small.

${ }^{12}$ This might result from a situation where at low levels of urbanization, increases in urbanization lead to lower labor force participation among women, so the gap is reduced only when incomes are sufficiently high enough to overcome transportation costs.

${ }^{13}$ Therefore our definition of "marriage" also includes cohabitation. 